\title{
Evaluation and Managing Wheat Seed-borne Diseases: Options and Suggestions from the Case of Tajikistan
}

\author{
B. Husenov ${ }^{1,2 *}$, S. AsaAd ${ }^{3}$, H. Muminjanov ${ }^{4}$, L. Garkava-Gustavisson ${ }^{1}$, \\ A. YORGANCILLAR ${ }^{5}$ and E. JOHANSSON ${ }^{1}$ \\ ${ }^{1}$ Department of Plant Breeding, The Swedish University of Agricultural Sciences (SLU), \\ Box 101, SE-230 53, Alnarp, Sweden \\ ${ }^{2}$ Agronomy Faculty, Tajik Agrarian University (TAU), 146, Rudaki ave., Dushanbe, Tajikistan \\ ${ }^{3}$ The International Centre for Agricultural Research in the Dry Areas (ICARDA), \\ P.O. Box 5466, Aleppo, Syria \\ ${ }^{4}$ FAO Sub-regional Office for Central Asia (FAO-SEC), \\ Ivedik Cad No55, Yenimahalle, 06170, Ankara, Turkey \\ ${ }^{5}$ Transitional Zone Agricultural Research Institute, 6km, Karabayir yolu, Eskishehir, Turkey \\ (Received 5 February 2016; Accepted 15 August 2016; \\ Communicated by A. Mohan)
}

\begin{abstract}
Wheat seed-borne diseases are among the major constraints reducing crop yield and the quality of seed and grain. In this study we aimed to evaluate the type and prevalence of fungal seed-borne diseases in Tajik wheat seed samples. Particular emphasis was given to common bunt resistance in advanced wheat breeding materials. Furthermore, we aimed to identify options for improving the seed quality. Seed samples collected from two different locations in Tajikistan were tested by conventional seed-health testing methods for presence of seed-borne diseases. Nineteen advanced wheat breeding lines and three varieties collected from the Tajik wheat breeding program were screened using an artificial inoculation test for their response to common bunt. Significant differences were found between the locations and genotypes concerning presence of common bunt and black point. Fourteen fungal species, where most of them are pathogenic for wheat, were identified in the seed samples. Tilletia laevis, T. tritici, Bipolaris sorokiniana, Stemphylium spp., and Drechslera spp. were the major pathogenic fungi observed in collected wheat samples. Common bunt was predominantly represented by $T$. laevis. No strong resistance was found in the studied Tajik wheat material, although a low percentage of infection was found in one line (SHARK/ F4105W2.1), while the material was evaluated for common bunt resistance. In managing seed-borne diseases, breeding of resistant varieties should be given a priority, while cultural practices such as preventing contamination and monitoring seed health status should also be considered, as a last resort the use of chemical seed treatments are advised.
\end{abstract}

Keywords: black point, common bunt, seed health, Tilletia spp., wheat breeding

\footnotetext{
*Corresponding author; E-mail: Bahromiddin.Husenov@slu.se
} 


\section{Introduction}

High grain yield and end-use quality are among the major breeding objectives of most wheat (Triticum aestivum L.) breeding programs around the world (Johansson et al. 2005; Ortiz et al. 2008). Similarly, Tajik wheat breeding programs have focused mainly on selection of new varieties with high yield capacity and resistance to the main foliar diseases, as well as with improved bread-making qualities (Rahmatov et al. 2010; Muminjanov et al. 2015). However, for wheat productions in Tajikistan, a number of major problems have been identified, including poor seed quality, low availability of superior varieties to the farmers, poor crop management and lack of financial investments (Mahmadyorov 2007; Rahmatov et al. 2010). One major concern related to wheat production systems in developing countries is the presence of so-called seed-borne diseases often associated with lack of sufficient amount of chemical fungicides to control diseases and use of farm saved seed without proper quality testing. In general, a high number of pathogens, including fungi, viruses, bacteria and nematodes, are transmitted with seed and such pathogens affect both the seed and grain quality (Pearce 1998). Among the seed-borne diseases of wheat, more than $70 \%$ are caused by fungi (Richardson 1996), and globally, bunts, smuts, black point, fusarium head blight and glume blotch are the most prevalent (Mathur and Cunfer 1993).

Common bunt or stinking smut is caused by two related fungi, Tilletia tritici (Bjerk.) Wint. and T. laevis Kühn (Wilcoxson and Saari 1996). Common bunt has been known since historic time by wheat growers and due to its effect on the yield and flour quality, there are restrictive import rules in place for preventing the spread of the disease (Mathur and Cunfer 1993; Majewski et al. 2011). Black point is the common name for a number of diseases that cause a discoloration of the wheat seed at the embryo site of the kernel (Culshaw et al. 1988). The cause of black point is mainly fungi, such as e.g. Alternaria spp., Drechslera spp. and Bipolaris sorokiniana (Mathur and Cunfer 1993; McIntosh 1998). Black point is also important due to its influence on the grain quality and grading (Fernandez and Conner 2011), as well as on germination rate and establishment in the field (Toklu et al. 2008).

In Tajikistan, information related to the presence of seed-borne diseases is scarce due to limited studies. Previously, seed-borne diseases have not been considered important enough to be included to the breeding objectives. Thus, the aim of the present study was to understand and define options to develop seed-borne disease-free wheat material and to propose a breeding strategy to decrease economic losses due to seed-borne diseases in developing countries like Tajikistan. Therefore, prevalence and type of seed-borne diseases were evaluated in Tajik wheat breeding material. Furthermore, resistance reactions and infection percentage were evaluated using common bunt as a case for possible resistance breeding. Finally, strategies to improve yield and quality of wheat grown in Tajikistan are discussed. 


\section{Materials and Methods}

\section{Plant material and their evaluation}

Bread wheat (Triticum aestivum L.), three varieties (selected as checks) and 19 advanced breeding lines obtained from the National Wheat Breeding Program of Tajikistan were used in all experiments (Table 1). The check varieties "Navruz" and "Alex", are bred by the Tajik Farming Institute (TFI) and are officially released in the country. The third check was "Starshina", a variety bred by Lukyanenko Research Institute of Agriculture, Krasnodar, Russian Federation, which are widely grown in Tajikistan. In addition to these mentioned varieties and lines, the variety "Norman" bread by the TFI was used as susceptible check in the experiments evaluating reaction of genotypes to common bunt in the field in Turkey and in the greenhouse in Sweden. The Swedish variety "Stava", known to be resistant to common bunt (Borgen and Davanlou 2001; Dumalasová and Bartoš 2006), was included in the greenhouse experiment as a resistant control. Advanced breeding lines included in this study were all originally received from the International Agricultural Research Centres (IARC), including CIMMYT (The International Maize and Wheat Improvement Centre, Mexico) and IWWIP (International Winter Wheat Improvement Program, Turkey) (Table 1). All plant materials investigated in the present study were collected from the Multilocation Yield Trial Nursery (MYTN) of the Tajik wheat breeding Program, where the last step of screening is conducted before submission of the best lines for official variety testing.

Wheat varieties/lines were evaluated in two different locations during two consecutive growing seasons in Tajikistan, i.e. during 2009-2010 and 2010-2011. Thereto, the genotypes were screened against common bunt in Turkey during the 2013-2014 growing season at one location. Screening varieties/lines for their reaction to common bunt was also conducted in greenhouse facilities in Sweden.

\section{Field trials in Tajikistan}

Advanced breeding lines and check varieties were sown in October at two different locations in Tajikistan. The experiments were conducted in the central-western part of Tajikistan, Hisor district, at Latif Murodov seed farm $\left(38^{\circ} 52^{\prime} \mathrm{N}\right.$; $\left.68^{\circ} 58^{\prime} \mathrm{E}, 780 \mathrm{masl}\right)$ and in the northern part of Tajikistan, Isfara district, at the Chilgazi seed farm $\left(40^{\circ} 09^{\prime} \mathrm{N}\right.$; $70^{\circ} 43^{\prime} \mathrm{E}$, 822 masl). Three replicates and randomized block design was applied. The harvest was carried out at the full ripening stage during the end of June the following year. The plot size was $14 \mathrm{~m}^{2}$ and the management of the trials was similar to production fields. All experiments were conducted under irrigation and the previous crop was maize. No seed treatment or pesticides were applied during the growing season. From flowering to full ripening the experimental plots were inspected twice for the presence of common bunt. If the disease was observed, the number of infected spikes per plot was counted and incidence was recorded as percentage of infected spikes per plot. Each field plot was harvested and sampled separately resulting in 66 samples from each location and 132 samples for both locations during 2010 and 132 samples during 2011. Collected samples were 
tested at the Seed Health Laboratory of the International Centre of Agricultural Research in the Dry Areas (ICARDA) in Aleppo, Syria.

Field experiments in Turkey were conducted in the Transitional Zone Agricultural Research Institute, Eskishehir $\left(3^{\circ} 46^{\prime} \mathrm{N} ; 30^{\circ} 31^{\prime} \mathrm{E}\right)$ during the 2013-2014 growing season. Seeds were artificially inoculated with a population of common bunt collected from the same zone. Materials were planted as 1 row $\times 1 \mathrm{~m}$. For each row infected spikes and healthy spikes were counted and percentage of disease incidence was estimated. In this experiment the following scaling was used: genotypes with common bunt infected spikes with less than $5 \%$ were considered as resistant $(\mathrm{R})$; genotypes with 5 to $10 \%$ of infected spikes were classified as moderate resistant (MR) and those with more than $10 \%$ as susceptible (S).

\section{Screening for common bunt resistance in greenhouse}

A common bunt resistance test of the plant material was conducted at greenhouse facilities of the Swedish University of Agricultural Sciences (SLU), Alnarp during the period from October 2012 to March 2013. Completely randomized design with three inoculated replications consisting of 10 plants in each replication was applied. Seeds were inoculated with a mixture of bunt spores (Tilletia laevis) collected from three locations in Tajikistan during the summer 2012: Mastchoh (north), N. Khusrav (south) and Muminobod (southeast). Each seed sample was separately inoculated by bunt spores in a tube, by shaking and mixing seed with common bunt spores for about two minutes. Inoculated seed were planted in greenhouse soil (Krukväxtjord med leca, Weibull Trädgård $\mathrm{AB}$ ). Plants at the seedling stage were moved to one vernalization room with a temperature of $4{ }^{\circ} \mathrm{C}$ for 8 weeks. Thereafter, the plants were grown in the greenhouse at 15 to $18{ }^{\circ} \mathrm{C}$ with relative humidity (RH) of 65 to $70 \%$. The first scoring was carried out just after heading, when initial symptoms become visible, and the following scoring was during dough stage of the seeds. For each plant the number of healthy and diseased spikes was counted and the percentage of damage calculated. Evaluation of disease resistance was similar to the experiments conducted in Turkey.

\section{Seed health testing}

To detect and identify the teliospores of Tilletia spp., the main cause of wheat common bunt, and other pathogenic fungi, the centrifuge wash test (CWT) was applied as described in Mathur and Kongsdal (2003). For this test, $25 \mathrm{~g}$ of seeds from each sample were soaked in $60 \mathrm{ml}$ of distilled water containing two drops of liquid soap. The sample was then shaken for one minute and thereafter the soaked samples were kept for 12-16 hours at room temperature (RT). The suspension was poured into tubes and centrifuged at $2000 \mathrm{rpm}$ (revolutions per minute) for 10 minutes. The obtained sediment after centrifugation was diluted in a $1 \mathrm{ml}$ solution of the supernatant and a new suspension was obtained. The suspensions obtained after centrifugation were checked under a compound microscope for presence of Tilletia spp. and other fungi at $\times 200$ magnification. In cases when a more precise check was needed, higher magnifications were used. 
The agar plate method was used in order to identify major fungal pathogens on the seed (Mathur and Kongsdal 2003). From each seed sample, $10 \mathrm{~g}$ of seeds were taken and surface sterilized with $0.2 \%$ sodium hypochlorite $(\mathrm{NaOCl})$. Each sample was thereafter dried on filter paper and placed on Petri dishes with potato dextrose agar (PDA) as the medium. Each sample was plated onto 10 Petri dishes (PD), containing 10 seeds each and black pointed seeds were marked as described below. Each PD was considered as a separate replicate. Seeds were incubated under 12 hours light and 12 hours dark for 12-14 days. Thereafter, fungal colonies were examined using stereomicroscope and compound microscope under different magnifications. Fungi were evaluated according to their colonies and spore characterization. For accurate results, reference books by Dugan (2008) and Barnett and Hunter (2006) were used for identification of fungi species.

\section{Percentage of seed infection with black point}

Wheat grains were evaluated for presence of dark brown or blackish discoloration, typical symptoms of black point (Mathur and Cunfer 1993). Proportion of black pointed grains was calculated and presented as percentage of grains with black point. Seed with black point symptoms were marked while plating on agar medium in order to determine the prevailing fungi in such seed.

\section{Statistical analyses and calculations}

Microsoft Excel was used in designing field and greenhouse trials to randomize tests and prepare raw data. Analyses of variance (ANOVA) was performed with statistical package Minitab v. 16 (Minitab 2010), in order to see the differences between varieties/lines as well as to evaluate the location and year effect with regard to infestation of seed-borne diseases. Differences between varieties/lines regarding common bunt resistance were checked applying the Tukey post hoc test $(\mathrm{P}<0.05)$ in Minitab.

Frequency of the samples where fungi were found in CWT were calculated as per below formula:

$$
\begin{gathered}
\begin{array}{c}
\text { Infection mean for individual genotype/location }= \\
(\text { Frequency of sample on which a fungus identified } \times 100 \%)
\end{array} \\
\text { Overall number of samples tested }
\end{gathered}
$$

\section{Results}

\section{Prevalence and type of seed-borne diseases}

The field incidence of common bunt was generally found to be low under natural conditions in all the studied wheat genotypes, although the incidence was slightly different between the two used locations in Tajikistan (Table 1). In the Chilgazi farm no field incidence was recorded during two consecutive years. In the Latif Murodov farm, four breed- 


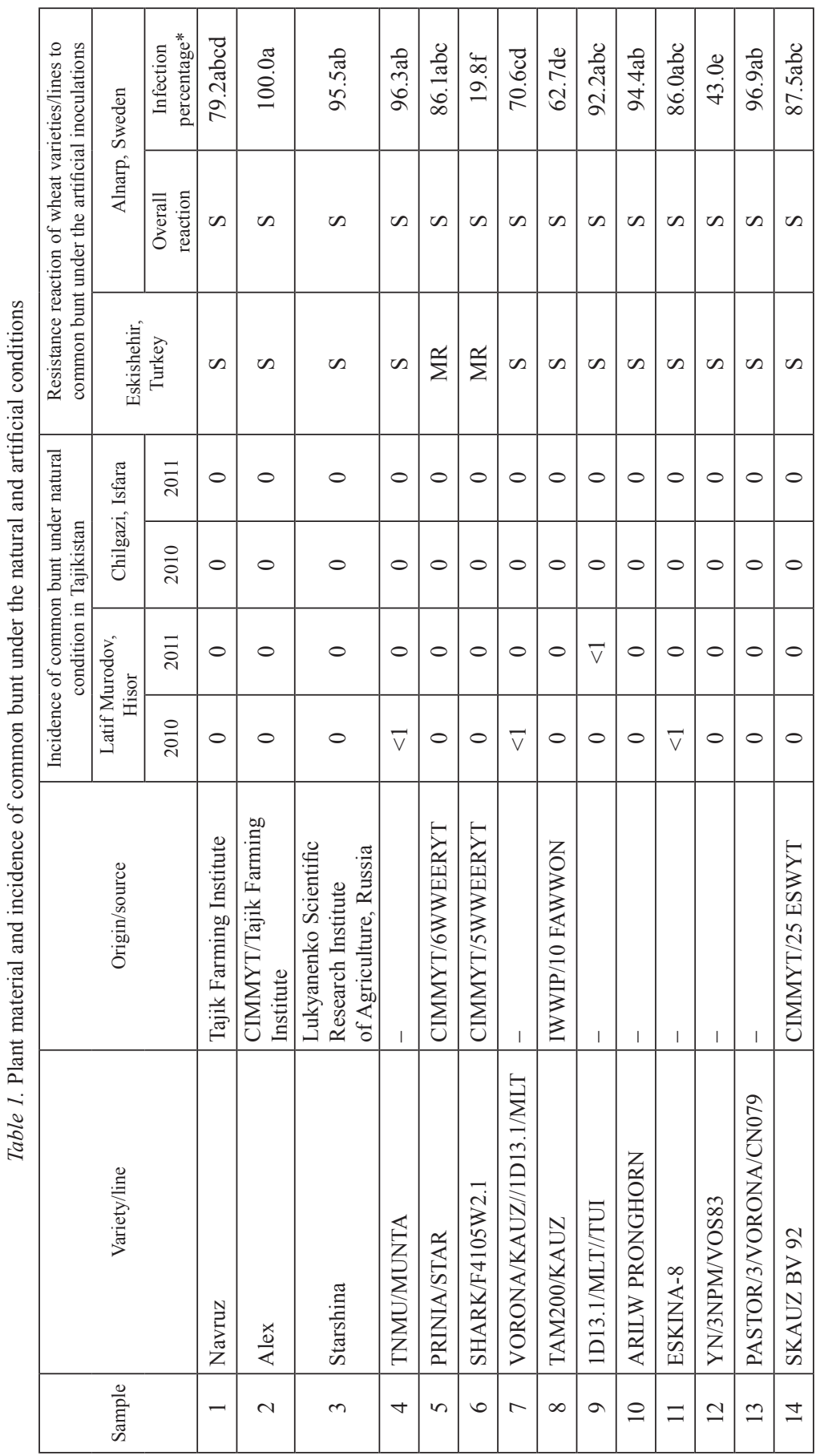




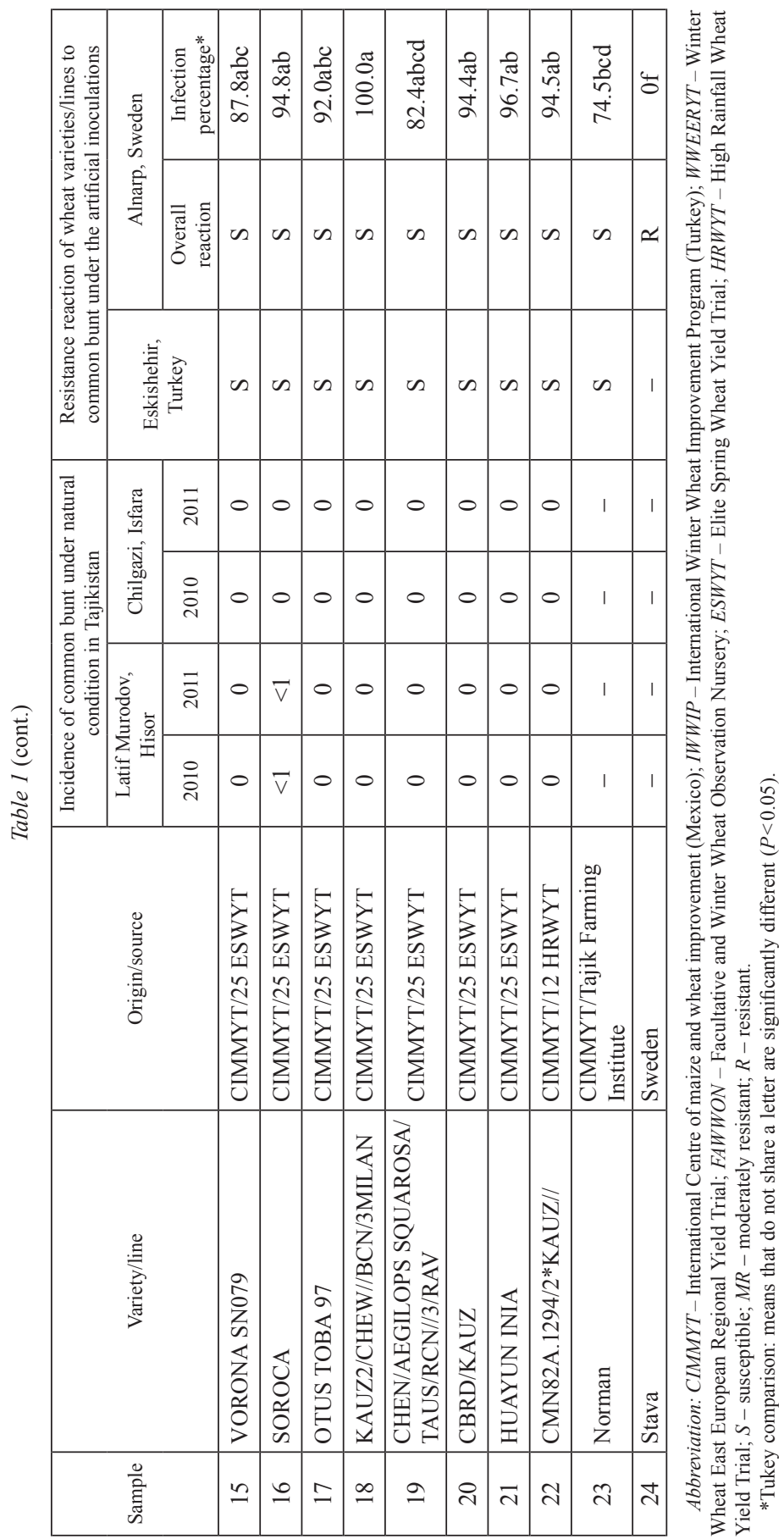


ing lines were found with common bunt incidence $(<1 \%)$ in 2010: TNMU/MUNTA, VORONA/KAUZ//1D13.1/MLT, ESKINA-8 and SOROCA, while two lines showed common bunt incidence $(<1 \%)$ in 2011: 1D13.1/MLT//TUI and SOROCA. Thus, SOROCA was the only genotype showing disease in both years. Although disease incidence was low, presence of inoculum was proven by CWT in both locations. Both Tilletia laevis and T. tritici were found in the wheat seed samples, whereas T. laevis was predominant in both locations. T. tritici was found only apparently in both locations, but predominantly in the samples of the Latif Murodov farm. Significant differences $(\mathrm{P}<0.001)$ were found between locations for the presence of T. laevis and T. tritici in the samples, but no significant differences were found between the two years. During both years samples collected at the Latif Murodov farm were infected to a higher degree with $T$. laevis compared to samples from Chilgazi farm.

Contrary to common bunt, black point was more common in samples from the Chilgazi farm as compared to samples from the Latif Murodov farm (Table 2). Black point infection varied among genotypes with low disease prevalence in both locations for Eskina-8 and YN/3NPM/VOS83 and a high prevalence for SOROCA and CBRD/KAUZ. $\mathrm{CBRD} / \mathrm{KAUZ}$ was the genotype showing highest black point infection at both locations. The fungi associated with the disease symptoms in seed as identified by the agar test were Alternaria spp., followed by Bipolaris sorokiniana, Drechslera spp., Fusarium graminarium and other Fusarium spp.

In total, fourteen fungal species were found on the present wheat material - Tilletia laevis, T. tritici, Ustilago tritici, Alternaria spp., Cladosporium spp., Bipolaris sorokiniana, Drechslera tritisi repentis, Stemphylium spp., Ulocladium, Epicoccum, Fusarium graminarium, Fusarium spp., Peniccilium spp. and Botrytis spp. The most frequently found pathogenic fungi identified in the agar test were B. sorokiniana, Drechslera spp. and Stemphylium spp., while less pathogenic fungi species Alternaria spp. and Cladosporium spp. were present in all the samples in both tests. Similarly as for T. laevis and T. tritici, higher levels were found of B. sorokiniana and Drechslera spp. on samples from the Latif Murodov farm compared to samples from the Chilgazi farm (Table 2).

\section{Screening for resistance against common bunt in Tajik wheat breeding lines}

The field experiment conducted in Turkey showed that only two of the advanced breeding lines were moderately resistant to common bunt: PRINIA/STAR and SHARK/F4105W2.1 (Table 1). All the remaining genotypes, including checks, were susceptible to the population of common bunt from the region used for infection. The evaluation of the genotypes in the greenhouse in Alnarp, Sweden, revealed that no genotype was resistant to common bunt (Table 1). Mean values of comparisons for the percentage of infection significantly showed the lowest values for the resistant variety Stava ( $0 \%)$ and the advanced breeding line SHARK/F4105W2.1 (19.8\%) (Table 1). 


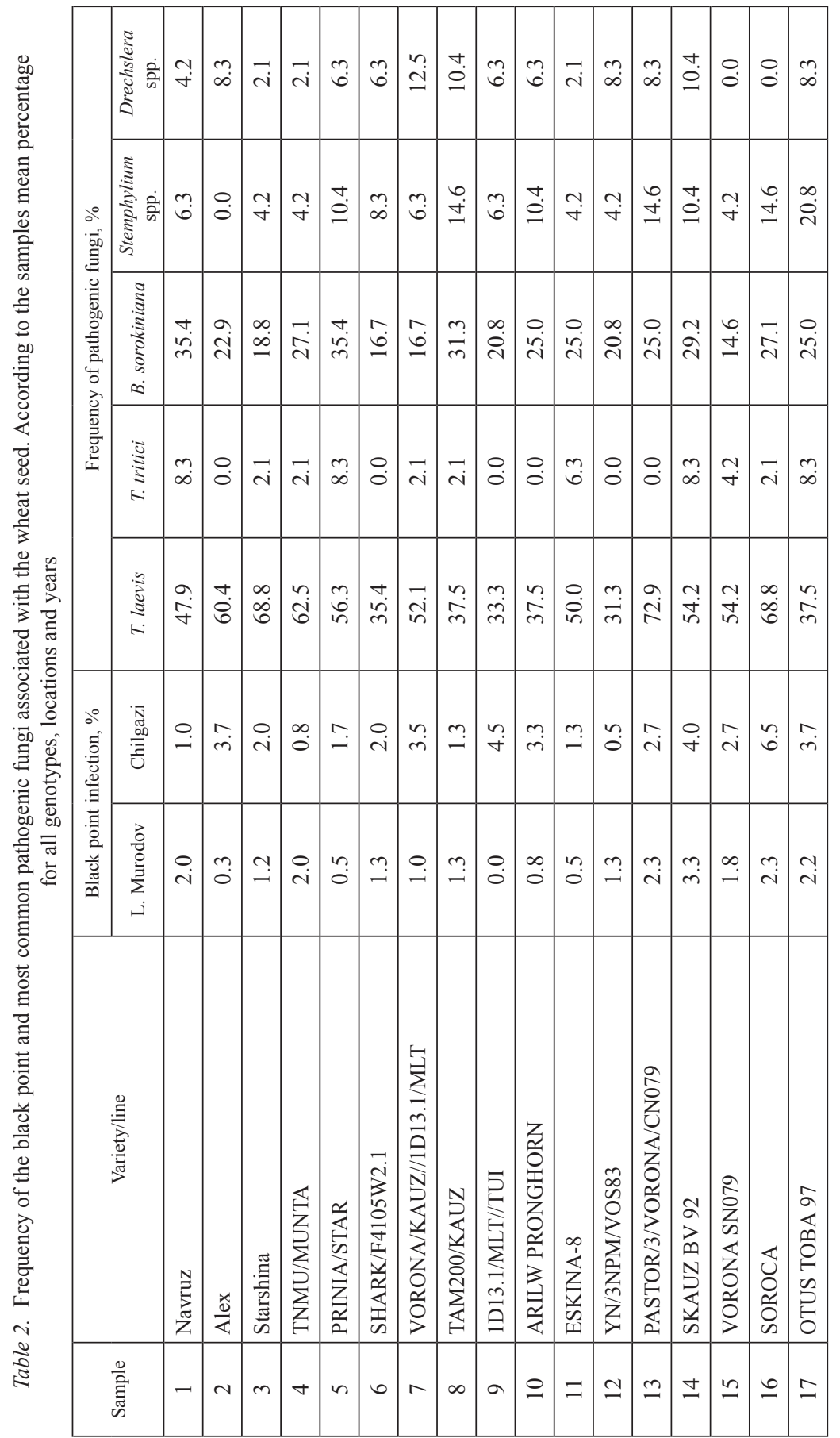




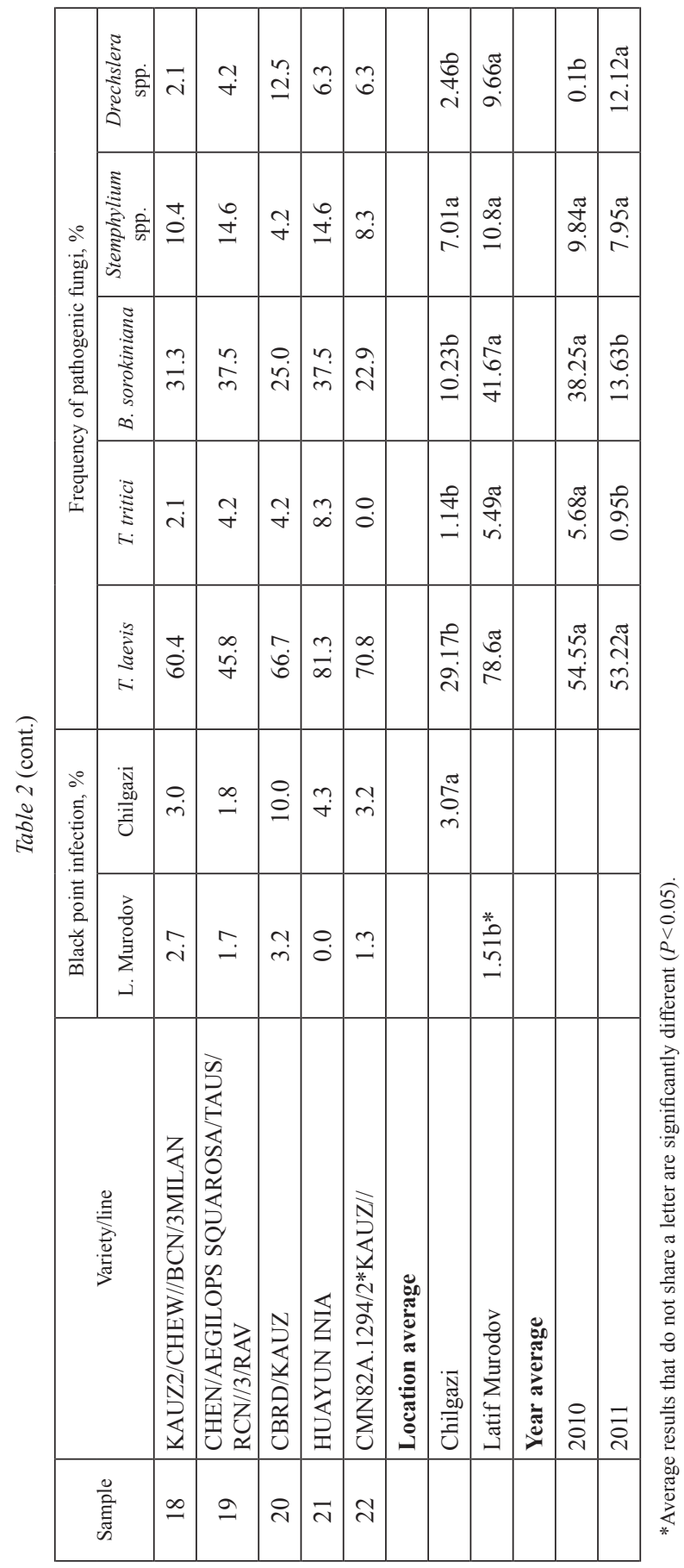

Cereal Research Communications 45, 2017 


\section{Discussion}

The present study clearly emphasizes the importance of understanding the reasons and background for the presence of seed-borne diseases in wheat breeding materials. An increased awareness and understanding is especially important in developing countries, such as Tajikistan, where most small scale farmers use saved seeds with no proper quality testing and treatment. Internationally, cases of $90 \%$ yield losses by seed-borne diseases have been reported for e.g. wheat blast epidemics in Bangladesh (Callaway 2016). In the mentioned case, the disease was probable transmitted to Bangladesh with grains originating from Brazil (https://github.com/crollab/wheat-blast). Common bunt has been reported the second most significant disease (after rusts) in various parts of Asia and Africa (Hoffman 1982) and common presence is reported in more recent studies (Pett et al. 2006; Asaad and Abang 2009).

Although presence of visually detectable infections of common bunt was low in the present wheat material, a more narrow inspection showed a high level of inoculum as well as black point and additional fungal species present on the seeds. Furthermore, a low level of resistance towards common bunt prevailed in the material, stressing the need of increased efforts in breeding for resistance and/or development of alternative strategies to manage the seed-borne diseases in the Tajik farming conditions.

In the present study, differences were found in field incidence and contamination of seeds from the two sampled locations, for common bunt, black point and also for tan spot, caused by $D$. tritici repentis. Higher levels of black point but lower levels of common bunt and tan spot were recorded for the Chilgazi farm, most likely due to the drier climate at this location. Similar to previous studies (Rees et al. 1984; Toklu et al. 2008), Alternaria spp. was found to be the predominant fungi species associated with black pointed grain in the present study, followed by Bipolaris sorokiniana, and Fusarium spp. In the present study Drechslera spp. was identified as a main contributor to black point as also reported by Pett et al. (2005).

Despite the fact that almost no common bunt resistance was seen in the present wheat material, only one breeding line (SHARK/F4105W2.1) was significantly close to the resistant check Stava, while evaluated for common bunt resistance in the greenhouse (Table 1). Stava has in its pedigree PI178383, which holds resistance genes Bt8, Bt9 and Bt10 (Blažková and Bartoš 1997). In studies conducted by Andrews and Ballinger (1987), lines with resistance genes $B t 8, B t 9$ or $B t 10$ showed sufficient resistance to common bunt. Our results show that plants of the breeding line SHARK/F4105W2.1 may also carry any of these resistance genes and infected plants present in this line may be the result of seed admixtures. The probable resistance in this line most likely originates from the Fundulea background (line F4105W2.1) of this line originating from the National Agricultural Research and Development Institute, Romania. Among this material, a number of lines resistant to common bunt have been identified within a program for bunt resistance (Ittu et al. 2001; Ciuca and Sãulescu 2008). A recent study evaluating breeding options for improved bread-making quality in Tajikistan has clearly pointed out the problems with heterogeneity of the breeding material (Husenov et al. 2015a). Another reason might be differences in the resistance reaction in field conditions as compared to the greenhouse as 
has been described in previous studies (Gaudet and Puchalski 1989). In the mentioned study, lines showing resistance to common bunt in the field were found, while they were susceptible in the greenhouse, which may be either escape in the field or may indicate presence of not yet revealed resistance mechanisms. Further studies with this materials may help to find the reason of the phenomena.

The major factors for obtaining high yield of wheat are to grow varieties well adapted to local conditions, and to use high quality and healthy planting materials (Van Gastel et al. 2002; Taylor et al. 2006). The advanced breeding lines used in this study were received from IARC and were selected for their good agronomic performance, as well as their resistance to major foliar diseases (Rahmatov et al. 2010). In managing seed-borne diseases, resistant varieties play a crucial role, and therefore efforts have been made to identify sources of disease resistance against, e.g. common bunt (Dumalasová and Bartoš 2006; Gaudet et al. 2007; Matanguihan et al. 2011) and black point (Conner and Davidson 1988; Christopher et al. 2007) in wheat. Wheat material originating from CIMMYT has been evaluated in Canada and limited resistance was found (Gaudet et al. 1995). Furthermore, only $4.5 \%$ of genotypes originating from CIMMYT grown in western Siberia (19711984) were found resistant to common bunt (Morgounov 1992). Incorporation of resistance to the major seed-borne diseases is crucial, especially in rain fed areas and in zones with high disease pressure, e.g. common bunt.

Another important aspect to consider is the hygienic status of the planting material. Despite that the spikes were relatively healthy looking during visual inspection, the presence of fungal spores was confirmed in all samples. Until now, there was no interest in Tajikistan regarding seed health status from neither producers nor farmers. Seed health tests are required for imported seeds only, and mainly for quarantine purposes (Muminjanov et al. 2008). Our study supports the importance of the seed health testing, especially for earlier generations of planting materials. The use of conventional seed health testing methods as the ones applied here has also been shown most useful in previous studies (Mezzalama 2010). The tests used are relatively inexpensive and applicable in developing countries like Tajikistan.

To conclude, seed-borne fungal pathogens causing common bunt, black point and different foliar spots were commonly found in the wheat breeding lines of the present study. The future research and plant-breeding directions should incorporate resistance in newly developed wheat materials in order to overcome the problem of seed-borne diseases in wheat produced in Tajikistan. To achieve this common bunt race analyses and survey for the presence of resistance genes in wide range of Tajik wheat materials should be incorporated in the breeding pipeline. Tajikistan is known as one of the centres of origin and diversity of a number crop species, including wheat. Tajik farmers managed to domesticate wheat and select landraces that are still grown in the country (Husenov et al. 2015b). In this regard, wheat landraces in addition to wild relatives could be used as a source of resistance to seed-borne diseases. Additionally, introducing seed health testing in seed certification is also an important step that will help to prevent economic losses. Using effective seed treatment in order to prevent serious losses from disease can be considered in critical cases as well. 


\section{Acknowledgements}

Authors are grateful to Sida funded Project "Support to Seed Sector Development in Tajikistan" for financial support and ICARDA for providing facilities for the laboratory analyses. All staff of the Seed Health Laboratory of ICARDA, Aleppo is also acknowledged for help during the analyses. We are also grateful to the wheat breeders of the Tajik national wheat-breeding program. We would like to thank Dr. Anders Borgen (Agrologica, Denmark) for providing seed of the resistant check (Stava) and for all his advice during the greenhouse experiment. Professor Inger Åhman of SLU is acknowledged for advice during work in Alnarp. Maria Luisa Prieto-Linde is acknowledged for taking care of the plants in the greenhouse. We would like to thank Dr. Alexey Morgounov and colleagues at Transitional Zone Agricultural Research Institute, Eskishehir, for help with the common bunt test in Turkey. Our sincere gratitude goes to Dr. William Newson for English editing. Authors also would like to acknowledge anonymous reviewers for their comments in improving the manuscript.

\section{References}

Andrews, J., Ballinger, D. 1987. Potential for bunt resistant wheats. Australasian Plant Pathol. 16:52-53.

Asaad, S., Abang, M. 2009. Seed-borne pathogens detected in consignments of cereal seeds received by the International Center for Agricultural Research in the Dry Areas (ICARDA), Syria. Int. J. of Pest Management 55:69-77.

Barnett, H.L., Hunter, B.B. 2006. Illustrated Genera of Imperfect Fungi. Fourth ed. The American Phytopathological Society. St. Paul, Minnesota, USA.

Blažková, V., Bartoš, P. 1997. Reaction of winter wheat cultivars registered in the Czech Republic to common bunt (Tilletia tritici (Bjerk.) Wint. and T. laevis Kühn) and sources of resistance. Cereal Res. Commun. 25:985-992.

Borgen, A., Davanlou, M. 2001. Biological control of common bunt (Tilletia tritici). J. of Crop Production 3:157-171.

Callaway, E. 2016. Devastating wheat fungus appear in Asia for first time. Nature: News in focus 532:421-422.

Christopher, M., Williamson, P., Michalowitz, M., Jennings, R., Lehmensiek, A., Sheppard, J., Banks, P. 2007. Simple sequence repeat markers associated with three quantitative trait loci for black point resistance can be used to enrich selection populations in bread wheat. Aust. J. of Agric. Res. 58:867-873.

Ciuca, M., Sãulescu, N. 2008. Screening Romanian winter wheat germplasm for presence of Bt10 bunt resistance gene, using molecular markers. Romanian Agric. Res. 25:1-5.

Conner, R., Davidson, J. 1988. Resistance in wheat to black point caused by Alternaria alternata and Cochliobolus sativus. Can. J. of Plant Sci. 68:351-359.

Culshaw, F., Cook, R., Magan, N., Evans, E. 1988. Blackpoint of wheat. HGCA Res. Review:1-43.

Dugan, F. 2008. The Identification of Fungi: an Illustrated Introduction with Keys, Glossary, and Guide to Literature. APS. St. Paul, Minnesota, USA.

Dumalasová, V., Bartoš, P. 2006. Resistance of winter wheat cultivars to common bunt, Tilletia tritici (Bjerk.) Wint. and T. laevis Kuhn. J. of Plant Disease Protection 113:159-163.

Fernandez, M., Conner, R. 2011. Black point and smudge in wheat. Prairie Soils and Crops J. 4:158-164.

Gaudet, D., Puchalski, B., Kozub, G. 1995. Reaction of CIMMYT and Canadian Red spring wheat cultivars to common bunt (Tilletia tritici and T. laevis). Cereal Res. Commun. 23(1/2):141-146.

Gaudet, D., Puchalski, B. 1989. Status of bunt resistance in western Canadian spring wheat and triticale. Can. J. of Plant Sci. 69:797-804. 
Gaudet, D., Lu, A., Leggett, F., Puchalski, B., Laroche, A. 2007. Compatible and incompatible interactions in wheat involving the Bt-10 gene for resistance to Tilletia tritici, the common bunt pathogen. Phytopathol. 97:1397-1405.

Hoffman, J. 1982. Bunt of wheat. Plant Dis. 66:979-986.

Husenov, B., Makhkamov, M., Garkava-Gustavsson, L., Muminjanov, H., Johansson, E. 2015a. Breeding for wheat quality to assure food security of a staple crop: the case study of Tajikistan. Agric. and Food Security 4:8.

Husenov, B., Otambekova, M., Morgounov, A., Muminjanov, H. 2015b. Wheat landraces in farmers' fields in Tajikistan: National survey, collection and conservation. FAO, Ankara, Turkey.

Ittu, M., Sãulescu, N., Ittu, G. 2001. Breeding approaches for bunt control in winter bread wheat. Beiträge zur Züchtungsforschung 7:42-47.

Johansson, E., Prieto-Linde, M., Kuktaite, R., Andersson, A., Jonsson, J., Svensson, G. 2005. Breeding for improved stability in bread-making quality. Using cereal science and technology for the benefit of consumers. Proc. 12th Int. ICC Cereal and Bread Congress. Harrogate, UK. pp. 44-48.

Mahmadyorov, U.M. 2007. Scientific justification of growing cereals and legumes as a second crop in irrigated lands of Central Tajikistan Doctoral diss. Tajik Agrarian University, Dushanbe (in Russian).

Majewski, J., Shankar, M., Loughman, R. 2011. Common bunt resistance in Western Australian wheat varieties. In: Peterson, J., Nicholls, C. (eds), Agribusiness Crop Updates. Western Australian Agriculture Authority. Perth, Australia, pp. 104-106.

Matanguihan, J.B., Murphy, K., Jones, S. 2011. Control of common bunt in organic wheat. Plant Dis. 95:92103.

Mathur, S., Cunfer, B. 1993. Seed-borne Diseases and Seed Health Testing of Wheat. Institute of Seed Pathology for Developing Countries. Danish Government. Frederiksberg, Denmark.

Mathur, S., Kongsdal, O. 2003. Washing test. In: Common Laboratory Seed Health Testing Methods for Detecting Fungi. First ed.. ISTA and Danish Institute of Seed Pathology for Developing Countries. Copenhagne, Denmark. pp. 71-88.

McIntosh, R. 1998. Breeding wheat for resistance to biotic stresses. Euphytica 100:19-34.

Mezzalama, M. 2010. Seed Health: Rules and Regulations for the Safe Movement of Germplasm (Second ed.). CIMMYT. Mexico, D.F., Mexico.

Minitab. 2010. Minitab 16 Statistical Software. http://www.minitab.com/en-us/products/minitab/

Morgounov, A. 1992. Wheat and Wheat Breeding in the Former USSR. CIMMYT. Mexico, D.F., Mexico.

Muminjanov, H., Berlin, A., Persson, R., Otambekova, M., Bishaw, Z. 2008. The Tajikistan Seed Industry. Focus on Seed Programs \#20. ICARDA, Aleppo, Syria, 12 p.

Muminjanov, H., Otambekova, M., Morgounov, A. 2015. The history of wheat breeding in Tajikistan. In: Bonjean, A.P., Angus, W.J., Maarten, V.G. (eds), The World Wheat Book, vol. 3. Lavoisier Publishing. Paris, France. pp. 283-305.

Ortiz, R., Braun, H.J., Crossa, J., Crouch, J., Davenport, G., Dixon, J., Dreisigacker, S., Duveiller, E., He, Z., Huerta, J. 2008. Wheat genetic resources enhancement by the International Maize and Wheat Improvement Center (CIMMYT). Genetic Resources and Crop Evolution 55:1095-1140.

Pearce, D. 1998. PCR as a tool for the investigation of seed-borne diseases. In: Bridge, P., Arora, D., Reddy, C., Elander, R. (eds), Applications of PCR in Mycology. CAB Int. Wallingford, UK, pp. 309-324.

Pett, B., Muminjanov, H., Morgunov, A., Madaminov, V., Rahmatov, M., Sarkisova, T. 2005. Wheat diseases and pests observation for selection of resistant varieties in Tajikistan. Agromeridian, Theor. and Appl. Agric. Res. J. 2:83-87.

Pett, B., Muminjanov, H., Morgounov, A. 2006. Monitoring of wheat diseases and pests in Tajikistan 2004. Agromeridian, Theor. and Appl. Agric. Res. J. 1:43-48.

Rahmatov, M., Husenov, B., Otambekova, M., Makhkamov, M., Eshonova, Z., Soliev, B., Karimov, M., Ibragimov, A., Hede, A., Morgounov, A., Muminjanov, H. 2010. Results of investigations on wheat breeding in Tajikistan News of the Academy of Sciences of Tajikistan 3:71-82. (in Russian).

Rees, R., Martin, D., Law, D. 1984. Black point in bread wheat - Effects on quality and germination and fungal associations. Aust. J. of Exp. Agric. 24:601-605.

Richardson, M.J. 1996. Seed mycology - centenary review. Mycological Res. 100:385-392. 
Taylor, E., Bates, J., Jaccoud, D. 2006. Diagnosis of Seedborne Pathogens. In: Basra, A.S. (ed.). Handbook of Seed Science and Technology. Food Product Press. Binghamton, NY, USA. pp. 649-676.

Toklu, F., Akgul, D., Bicici, M., Karakoy, T. 2008. The relationship between black point and fungi species and effects of black point on seed germination properties in bread wheat. Turkish J. of Agric. and Forestry 32:267-272.

Van Gastel, A., Bishaw, Z., Gregg, B. 2002. Wheat seed production. In: Curtis, B., Rajaram, S., Gómez Macpherson, H. (eds), Bread Wheat: Improvement and Production. FAO. Rome, Italy. pp. 463-481.

Wilcoxson, R.D., Saari, E.E. (eds) 1996. Bunt and Smut Diseases of Wheat: Concepts and Methods of Disease Management. CIMMYT. Mexico, D.F., Mexico. 